\title{
Video-Assisted Thoracoscopic Removal of a Mysterious Foreign Body Causing Pneumothorax
}

\author{
Pnömotoraksa Neden Olan Gizemli Yabancı Cismin Video-Yardımlı \\ Torakoskopik Cerrahi ile Çıkarılması
}

Serkan Yazgan, Banu Yoldaș, Soner Gürsoy

\begin{abstract}
The removal of foreign bodies from the pleural cavity via video-assisted thoracoscopic surgery (VATS) has seldom been reported in the literature. This is a description of the case of a 31 -year-old female patient who presented with secondary pneumothorax due to a foreign body. The patient did not have any information about the foreign body. The metallic object was successfully removed with VATS, and it was discovered that the object was a broken injection needle. This inexplicable circumstance issue was referred to the legal department of the hospital. Videothoracoscopic removal is the safest procedure for intrapleural foreign objects.
\end{abstract}

Key words: Foreign body, needle, pneumothorax, video-assisted thoracic surgery (VATS).

Removal of foreign bodies from the pleural cavity using VATS has seldom been reported in the literature $(1,2)$. Thoracic surgeons mostly use VATS or thoracotomy under general anesthesia for foreign body removal from the chest wall or the pleural cavity (1-4). However, there is no consensus with regard to treatment (1). Nonetheless, foreign bodies in the pleural cavity should be removed when possible $(1,2)$. Otherwise, pneumothorax or empyema may develop. In this report, the case of a

\section{Özet}

Plevral kaviteden videotorakoskopik olarak yabancı cisim çıkarılması literatürde oldukça nadirdir. Bu sunuda etiyolojisi aydınlatılamamış olan intraplevral yabancı cisme bağlı pnömotoraks olgusu ve tedavisine yer verilmiştir. Radyolojik olarak sol plevrada ve karaciğerde metalik objeler görülen, 31 yaşındaki bayan hasta, bu yabancı cisimler hakkında herhangi bir bilgiye sahip değildi. Metalik obje video-yardımlı torakoskopi (VATS) ile başarılı biçimde çıkarıldı ve kırılmış bir enjektör iğnesi olduğu anlaşıldı. Bu açıklanamayan durum hastanenin hukuk birimine bildirildi. Plevral aralıkta saptanan yabancı cisimlerin çıkarılmasında, VATS'ın güvenle uygulanabileceğinin alıını çizmek isteriz.

Anahtar Sözcükler: Yabancı cisim, iğne, pnömotoraks, video-yardımlı torakoskopik cerrahi (VATS).

needle found in the pleural cavity in which the patient had no history of such foreign body penetration is described.

\section{CASE}

A 31 -year-old woman with secondary pneumothorax was referred to our department. There was no significant disorder in her history. Her laboratory tests were normal. Chest radiography showed a
Department of Thoracic Surgery, University of Health Sciences, Dr. Suat Seren Chest Diseases and Thoracic Surgery, Medical Practice and Research Center, İstanbul, Turkey
Sağlık Bilimleri Üniversitesi, Dr. Suat Seren Göğüs Hastalıkları ve Göğüs Cerrahisi Cerrahisi SUAM, Göğüs Cerrahisi Bölümü, İstanbul

Submitted (Başvuru tarihi): 31.12.2017 Accepted (Kabul tarihi): 31.01.2018

Correspondence (iletișim): Serkan Yazgan, Department of Thoracic Surgery, University of Health Sciences, Dr. Suat Seren Chest Diseases and Thoracic Surgery, Medical Practice and Research Center, İstanbul, Turkey

e-mail: serkanyazgan@gmail.com 
large left pneumothorax and a foreign body in the left upper hemithorax (Figure 1a). The patient had no history of foreign body aspiration. Physical examination did not reveal any entrance site through the skin. No subcutaneous erythema was detected. A chest tube was inserted immediately to treat the pneumothorax and the radiograph was repeated some hours later. When this chest radiography was carefully examined, other foreign bodies were also observed in the patient's abdomen (Figure $1 \mathrm{~b}$ ). Computerized tomography demonstrated metallic objects ( 2 needles) in the liver and a needle in the left infraclavicular area in the pleural cavity extending from the chest wall (Figure 2).
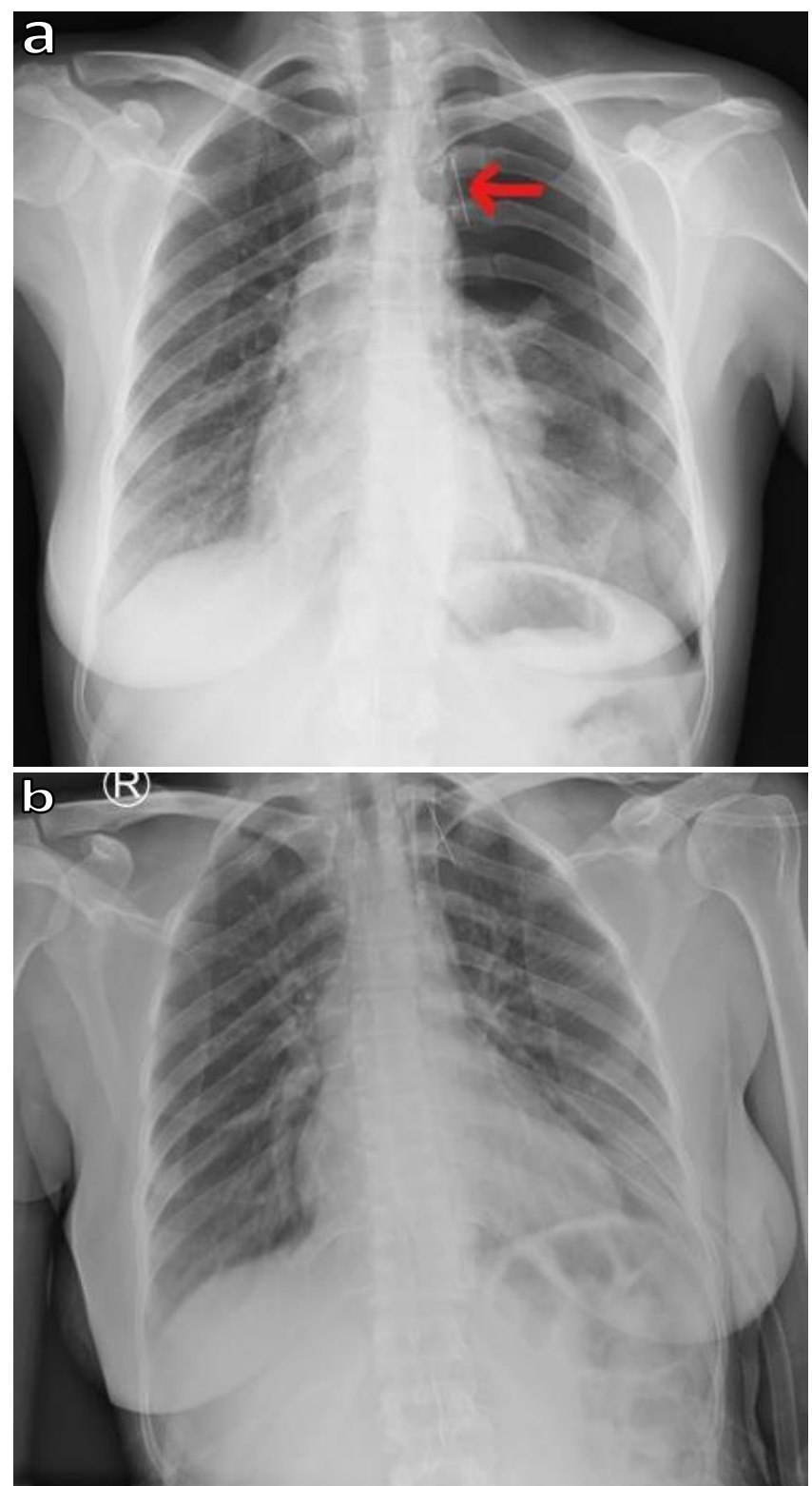

Figure la and b: Chest radiograph demonstrating left-sided pneumothorax and a needle (red arrow) located between the fourth and fifth posterior ribs in the left hemithorax (a). Chest radiograph showing the chest tube and expansive left lung, as well as 2 needles in the region of the lumbar vertebra (b)

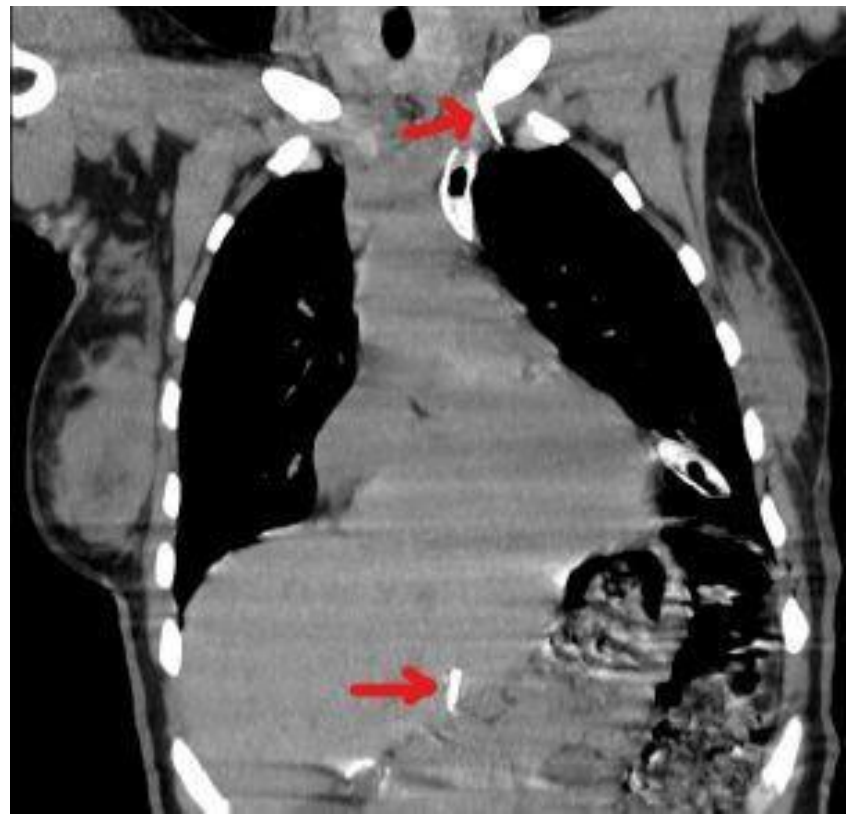

Figure 2: Coronal computed tomography scan showing a needle (red arrow) in the left upper hemithorax and another needle (red arrow) in the liver

The patient agreed to undergo video-assisted thoracoscopic surgery (VATS) to remove the pleural cavity foreign body. VATS provided clear visualization of the needle penetrating the parietal pleura (Figure 3a). The needle was removed using endoscopic grasping forceps, and it was determined to be a broken injection needle (Figure 3b). Chest tube drainage was maintained until the second day after the operation. There was no evidence of pneumothorax on a follow-up chest radiograph. A general surgery consultation was conducted regarding the foreign bodies in the abdomen. No surgery was planned for the needles in the liver. No psychiatric illness was detected following a psychiatric consultation. The removed needle was delivered to the legal department of the hospital. The patient was discharged on the third day after the operation.

\section{DISCUSSION}

An intrapleural foreign body causing pneumothorax is exceedingly rare and few cases have been documented in the literature. Previous studies indicate that the etiology is most commonly secondary to iatrogenic injury, or an intentional traumatic or accidental event (1). Brodsky et al. (5) reported the first thoracoscopic removal of foreign bodies from the pleural space with single lung ventilation in 1981. In recent years, thoracic surgeons have begun to use VATS and better, technically advanced videoendoscopy instruments to remove foreign bodies in the pleural space with $(3,6,7)$. 


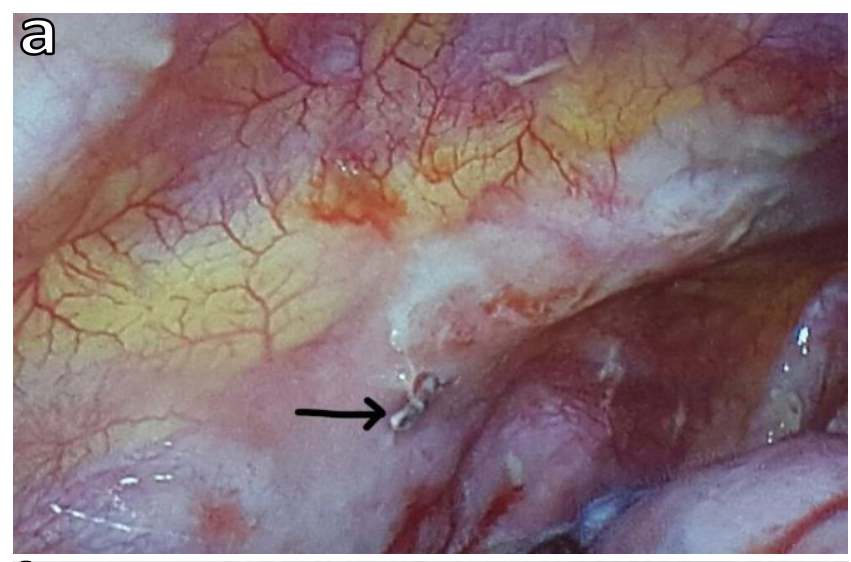

b

Figure 3a and b: Video-assisted thoracoscopic view of a needle (black arrow) penetrating the left upper hemithorax and the parietal pleura (a). The removed broken injection needle (b)

Foreign bodies entering the pleural space are categorized as the result of inhalation or passing through the chest wall from the exterior (7). Some foreign bodies in the pleural space may be incidentally detected radiographically, or they may be detected due to complications, such as secondary pneumothorax. In our case, first, we determined a large left pneumothorax, and then we realized that there were several foreign bodies present. Additional workups led to the discovery of 3 foreign bodies in total: one in the pleural space extending from the chest wall, and 2 in the liver. These shiny metal objects looked like needles. The patient underwent surgery and we removed the pleural cavity foreign body via VATS. When we examined the surgically removed foreign body, we realized that it was a broken injection needle. It was interesting, because neither our patient nor her family could provide any clue as to how the needles might have come to be in the pleural space and the liver. The patient had no psychiatric history or history of needle ingestion or aspiration. It was both interesting and suspicious. Since we thought there might be an unlawful aspect to the incident, the hospital legal department was informed.

\section{CONCLUSION}

It is rare for a needle to pass into the pleural space. Complications, such as pneumothorax, empyema, or vascular injury, should be considered and should be eliminated when possible (8). VATS removal is the safest procedure for intrapleural foreign objects or those embedded in the chest wall.

\section{CONFLICTS OF INTEREST}

None declared.

\section{AUTHOR CONTRIBUTIONS}

Concept - S.Y., B.Y., S.G.; Planning and Design - S.Y., B.Y., S.G.; Supervision - S.Y., B.Y., S.G.; Funding - S.Y., B.Y.; Materials - S.Y., B.Y.; Data Collection and/or Processing - S.Y.; Analysis and/or Interpretation - S.Y.; Literature Review - S.Y.; Writing - S.Y., B.Y.; Critical Review - S.Y., B.Y., S.G.

\section{YAZAR KATKILARI}

Fikir - S.Y., B.Y., S.G.; Tasarım ve Dizayn - S.Y., B.Y., S.G.; Denetleme - S.Y., B.Y., S.G.; Kaynaklar - S.Y., B.Y.; Malzemeler - S.Y., B.Y.; Veri Toplama ve/veya İşleme S.Y.; Analiz ve/veya Yorum - S.Y.; Literatür Taraması S.Y.; Yazıyı Yazan - S.Y., B.Y.; Eleştirel İnceleme - S.Y., B.Y., S.G.

\section{REFERENCES}

1. Weissberg D, Weissberg-Kasav D. Foreign bodies in pleura and chest wall. Ann Thorac Surg 2008; 86:95861. [CrossRef]

2. Tie ST, Wong JL, Kannan SK, Rahman JA. Pleuroscopic retrieval of a sewing needle from the pleural cavity under conscious sedation by a chest physician. J Bronchology Interv Pulmonol 2012; 19:246-8. [CrossRef]

3. von Riedenauer WB, Baker MK, Brewer RJ. Video-assisted thoracoscopic removal of migratory acupuncture needle causing pneumothorax. Chest 2007; 131:899-901. [CrossRef]

4. Urschel JD, Miller JD, Bennett WF. Self-inflicted pneumothoraces. Ann Thorac Surg 2001; 72:280-1. [CrossRef]

5. Brodsky JB, Welti RS, Mark JB. Thoracoscopy for retrieval of intrathoracic foreign bodies. Anesthesiology 1981; 54:91-2.

6. 6. Yu PS, Chan HH, Lau RW, Capilli FG, Underwood MJ, Wan IY. Penetrating thoracic injury with retained foreign body: can video-assisted thoracic surgery take up the leading role in acute management? J Thorac Dis 2016; 8:2247-51. [CrossRef] 
7. Ekeke C, Noble S, Merritt RE. Management of an intrapleural foreign body and empyema with video-assisted thoracoscopy. J Thorac Dis 2016; 8:2241-3. [CrossRef]
8. Apilioğulları B, Yoldaş B, Esme H, Bekçi TT. An unusual self-inserted foreign body in the mediastinum and its management: a case report. Turk Gogus Kalp Dama 2013; 3:810-2. [CrossRef] 